\title{
On the Identity of Tyrophagus putrescentiae (Schrank) and T. dimidiatus (Hermann) (Acarina, Acaridae) in Japan ${ }^{1)}$
}

By

\author{
M. Sasa ${ }^{2)}$, S. Oshima ${ }^{3)}$, K. Matsumoto4) and R. N. Sinha ${ }^{5)}$
}

There were some confusions over the taxonomic status of the two cosmopolitan species of Tyrophagus (Acarina; Fam. Acaridae) in some parts of the world (Oudemans 1906, Zakhvatkin 1941, Türk and Türk 1957, Robertson 1959. 1961, Sasa 1965). In Japan, the name $T$. dimidiatus (Hermann, 1804) has been generally applied to the common mite pest of stored food ever since Asanuma (1949, 1950) published his papers on stored product mites (Miura and Sasa 1961, Matsumoto 1962, Sasa 1964). Nevertheless, Asanuma (1950), had some reservation over the identity of this species when he stated "The author wishes to adopt with some hesitation the scientific name for this common species". Sasa (1964) summed up the situation by stating that the species most commonly found in Japan in the widest range of food materials was "conventionally identified" as $T$. dimidiatus by the Japanese acarologists. The Japanese common name of this species is "Kenagakonadani". It is generally found on rice, wheat, and barley seeds in stores, urban and rural granaries (Sinha 1967), cereals, flour, powdered milk, cheese, dried fish, drugs, chocolate, cookies, rice straw mat, and in various other foodstuffs consumed by the Japanese (Sasa 1964, Matsumoto 1962). Only in one Japanese report (Oshima 1964), however, this species was referred to as $T$. putrescentiae

1) A part of this paper was presented at the 17th Annual Meeting of the Japan Society of Sanitary Zoology (Eastern Area), Urawa city in 1966. Contribution No. 271 from the Research Station, Canada Department of Agriculture, Winnipeg, Canada.

2) The Institute of infectious Diseases, The University of Tokyo, Tokyo. Japan.

3) Division of Sanitary Zoology, Yokohama Municipal Institute of Public Health, Yokohama, Japan.

4) Department of Parasitology, Tokyo Women's Medical College, Tokyo, Japan.

.5) Canada Department of Agriculture Research Station, Winnipeg, Canada.
(Schrank, 1781).

To resolve the question of mistaken identity of this species the present authors met at the University of Tokyo in December 1966, examined specimens in their collections using the most recent key for the genus Tyrophagus (Hughes 1961), and agreed unanimously that $T$. putrescentiae was the correct name for the commonest and the most important species of the stored-product mite in Japan. As far as we could ascertain $T$. dimidiatus $(=T$. oudemansi Robertson, 1959) has not been reported from Japan although it occurs on plants, such as spinach, salsify, mullein, lily, poppy, petunia, rye, barley in Europe, U. K., U. S. A., and Australia.

These two valid species can be distinguished as follows (modified from Hughes 1961) :

1 Supracoxal seta (pseudostigmatic hair) curved, tapering evenly from base to tip, pectinate along its whole length; in dorso-ventral view of male, arms of penis support turned inwards ; dorsal setae $d_{2}$ short and almost equal in length with $d_{1}$ and $l_{\mathrm{a}}$, always less than half the length of chelicerae; appendages usually well-tanned $\cdots \cdots \cdots \cdots T$. dimidiatus Supracoxal seta (pseudostigmatic hais) usually straight with long pectinations only about its enlarged base; in dorsoventral view of male arms of penis turned outwards; dorsal setae $d_{2} 2$ to 3.5 times as long as $d_{1}$; appendages never well-tanned $\cdots \cdots \cdots \cdot T$. putrescentiae

\section{REFERENCES}

1) Asanuma, K. (1949): Mites on food. Shokuhin-Eisei, 1(2) : 42-44 (in Japanese). - 2) Asanuma, K. (1950): Agricultural stored food and flour mites (1). Noyaku to Byôchû, 4(8): 249-253 (in Japanese). - 3) Hughes, A. M. (1961): The Mites of Stored Food. H. M. Stationary Office, London, 287 pp. - 4) Matsumoto, K. (1962): Studies on the environmental factors for the breeding of grain mites. Part II. On the breeding of Tyrophagus 
dimidiatus in varjous stored food productc. Jap. J. Sanit. Zool., 13(1) : 16-19 (in Japanese). - 5) Miura, A. and M. Sasa (1961): Observations on the life cycle of the common grain mite, Tyrophagus dimidiatus (Hermann) by individual rearings. Jap. J. Exp. Med., 31(5) : 333-339. -6) Oshima S. (1964): Obervations of floor mites collected in Yokohama. I. On the mites found in several schools in summer. Jap. J. Sanit. Zool., 15(4) : 233-244. - 7) Oudemans, A. C. (1906): "Acari, Nova Guinea. Resultats de l'expéditiòn scientifique Neirlandaise à la Nouvelle-Guinée en 1903, sous les auspices de Arthur Wichmann, Chef de l'Expéditiòn". Vol. 5, Book 1. 101-162. (E. J. Brill : Ledien.). - 8) Robertson, P. L. (1959): A revision of the genus Tyrophagus, with a discussion on its taxonomic position in the Acarina. Austr. J. Zool., 7(2) : 146-181. - 9) Robertson, P. L. (1961): A morphological study of variation in Tyrophagus (Acarina), with particular reference to populations infesting cheese. Bull. Entomol. Res., 52(3) : 501-529. - 10) Sasa, M. (1964): Special problems of mites in stored food and drugs in Japan. Acarologia, 6 : 390-391 (Proc. 1st Intnat. Congr. Acarology, Fort Collins, Colorado, U. S. A., 1963). - 11) Sasa, M. (1965) : Mites, an introduction to classification, Bionomics and Control of Acarina. Univ. of Tokyo Press, Tokyo. 1-486. (in Japanes). - 12) Sinha, R. N. (1967): Seasonal changes in mite populations in rural granaries in Japan. Ann. Entomol. Soc. Amer. (in Press). 13) Türk, E. et Türk, F. (1957) : Beiträge zur Systematik und Ökologie Mitteleuropäischer Acarina. I(1), No 1, Tyroglyphiden. Akademische Verlagsgesellschaft Geest \& Portig K. -G., Leipzig.
1-384. - 14) Zakhvatkin, A. A. (1941): Fauna of USSR Arachnoidea. Vol. 6, No. 1. Tyroglyphoidea (Acari) (in Russian) (Engl. Transl. and Ed. by A. Ratcliffe and A. H. Hughes. 1959. Amer. Inst. Biol. Sci., Washington, D. C. 573 pp.).

\section{摘 要}

日本産の重要な食品害虫の一つであるケナガコナダニ にたいして，わが国では浅沼 (1949，1950) 以来 Tyrophagus dimidiatus (Hermann, 1804)が採用されてき た.この問題につき疑問をもつたわれわれは種々検討し た結果, Hughes(1961)の Tyrophagus 属のもつとも新 しい分類にしたが，ケナガコナダニの学名には Tyrophagus putrescentiae (Schrank, 1781) が適当であると いうことに意見が一致した．また野外種とされている T. dimidiatus はいまだ日本では報告されていないこと が確認された。

なおこれら両種は次の特徴によつて区別される。

基節上毛 $(\mathrm{PO})$ は曲がり，基部から先端に次第に細ま る，分枝はその長さ全体におよぶ，雄を背腹から見る 上, 陰茥支持器の腕は内側に曲がる. 背剛毛 $d_{2}$ は短 く, ほとんど $d_{1}$ と $l a$ の長さに等しく, 常に鋏角の長 さの半分より短い，付属肢は一般の茶褐色を呈す.

$$
\cdots \cdots \cdots \cdots \cdots+\text {. dimidiatus }
$$

基節上毛は一般に真直で，長い分枝はその膨大した基 部のまわりのみから生ずる. 雄を背腹から見ると, 陰茎 支持器の腕は外側に曲がる. 背剛毛 $d_{2}$ は $d_{1}$ の長さの 2 ないし 3.5 倍の付属肢はさほど茶褐化しない。

\section{T. putrescentiae}

\section{ショウドゥッバメのマダニ}

\section{Ixodes lividus (C. L. Koch 1844): A bird tick new to Japan}

Ixodes lividus (C. L. Koch 1844) (日本末記録)

Don. R. Arthur, 1963, British Ticks, p. 82-92, f. 91-116.

調查標本：25 今 20 우 1 nymph (with Ceratophyllus riparius riparius 2 우), 1962 年秋の道路改修工事のため 崖がけずられむきだしになつて冬を越したショウドウツ バメ Riparia riparia ijimai の巢材約 15 から，1963III-30, 網走市郊外藻琴湖畔国道 244 号 線ぞいの崖, 大 野採(網走の当日の平均気温 $-0.7 \mathrm{C}^{\circ}$; オホーツク海は一

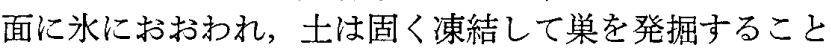
はできなかつた)。
2 우 (with Ceratophyllus riparius riparius 1 의 1 우, Ceratophyllus gallinae dilatus 8 今 9 우), 発掘した ショウドウツバメの单材 3 から, 上と同じ場所，1966VIII-4, 大野採(ショウドウツバメの巣穴はスズメによ つて屡々利用されることが観察された).

標本の 1 部は Dr. Don. R. Arthur によつて I. lividus であることが確認された，筆者はこれまでに上記藻 琴湖畔のほかに, 網走支庁女満別町, 同小清水町, 釧路 支庁白糠町でもショウドウツバメの巣を調べているが， これらの地域ではまだマダ二は発見されていない，本種 はショウドウツバメを宿主としイギリス，フランス，ド イツ，ソ聯(カザック)に知られる.

Dr. Don. R. Arthur 並びに文献について援助を頂い た北大山下次郎教授に深謝の意を表する.

（北海道衛研，大野善右衛門） 